\title{
An anti-CD6 monoclonal antibody (itolizumab) reduces circulating IL-6 in severe COVID-19 elderly patients
}

Danay Saavedra ${ }^{*}$ (D), Ana Laura Añé-Kourí ${ }^{2}$, Naivy Sánchez ${ }^{3}$, Lázaro Manuel Filgueira ${ }^{4}$, Julio Betancourt ${ }^{4}$, Carlos Herrera ${ }^{4}$, Leniel Manso ${ }^{4}$, Elibet Chávez ${ }^{5}$, Armando Caballero ${ }^{4}$, Carlos Hidalgo ${ }^{3}$, Geydi Lorenzo', Meylan Cepeda ${ }^{1}$, Carmen Valenzuela ${ }^{1}$, Mayra Ramos$^{1}$, Kalet León ${ }^{1}$, Zaima Mazorra ${ }^{1}$ and Tania Crombet $^{1}$

\begin{abstract}
Background: Since the COVID-19 outbreak an unprecedented challenge for healthcare systems around the world has been placed. In Cuba, the first case of COVID-19 was reported on March 11. Elderly with multiple comorbidities have been the most risky population. Although most patients present a mild to moderate disease, some have developed severe symptoms. One of the possible mechanisms underlying rapid disease progression is a cytokine storm, in which interleukin (IL) -6 seems to be a major mediator. Itolizumab is a humanized recombinant anti-CD6 monoclonal antibody (MAb), with the ability of reducing serum interferon gamma (INF- $\gamma$ ), tumour necrosis factor alpha (TNFa) and IL-6. Based on these previous results in patients with psoriasis and rheumatoid arthritis, an expanded access clinical trial was approved by the Cuban regulatory agency for COVID-19 critically, severely and moderately ill patients.
\end{abstract}

Results: We show here a short kinetic of IL-6 serum concentration in the first 24 COVID-19 patients treated with itolizumab. Most of patients were elderly with multiple comorbidities. We found that with one itolizumab dose, the circulating IL-6 decreased in critically and severely ill patients, whereas in moderately ill patients the values didn't rise as compared to their low baseline levels.

Conclusion: These findings suggest that itolizumab could be an attractive therapeutic option to decrease the negative outcome of the cytokine storm in COVID-19 patients.

Trial registration: CECMED IIC RD-EC 179, RPCEC00000311. Registered 4 May 2020 - Retrospectively registered, http://rpcec.sld.cu/ensayos/RPCEC00000311-Sp or http://rpcec.sld.cu/trials/RPCEC00000311-En

Keywords: COVID-19, IL-6, Itolizumab, Cytokine release syndrome

\footnotetext{
* Correspondence: danays@cim.sld.cu

'Department of Clinical Immunology. Center of Molecular Immunology, 216

St, Corner 15, PO Box 16040, Havana, Atabey, Cuba

Full list of author information is available at the end of the article
}

(C) The Author(s). 2020 Open Access This article is licensed under a Creative Commons Attribution 4.0 International License, which permits use, sharing, adaptation, distribution and reproduction in any medium or format, as long as you give appropriate credit to the original author(s) and the source, provide a link to the Creative Commons licence, and indicate if changes were made. The images or other third party material in this article are included in the article's Creative Commons licence, unless indicated otherwise in a credit line to the material. If material is not included in the article's Creative Commons licence and your intended use is not permitted by statutory regulation or exceeds the permitted use, you will need to obtain permission directly from the copyright holder. To view a copy of this licence, visit http://creativecommons.org/licenses/by/4.0/ The Creative Commons Public Domain Dedication waiver (http://creativecommons.org/publicdomain/zero/1.0/) applies to the data made available in this article, unless otherwise stated in a credit line to the data. 


\section{Background}

The Severe Acute Respiratory Syndrome Coronavirus 2 (SARS-CoV-2) has caused a recent outbreak of Coronavirus Disease (COVID-19) [1, 2]. The disease started in Wuhan, China in December 2019 and has rapidly spread throughout the world [1]. To date, the disease has already affected more than five million globally, with a $6.48 \%$ of mortality. In Cuba, the first case of COVID-19 was reported on March 11, 2020. Since then, the number of positive cases has risen to 1947 cases, according to government data on May 25, 2020. Notably, the epidemiological curve is decreasing, moving forward daily reduction of the cases.

Although most cases are mild to moderate, some patients developed severe symptoms characterized by respiratory dysfunction and/or multiple organ failure that causes the death in most cases [3]. Previous studies have revealed that patients with old age and comorbidities such as hypertension and diabetes are more likely to be aggravated $[4,5]$.

Altered immune competence with increasing age, defined as immunosenescence and the state of chronic, sterile, low-grade inflammation known as inflammaging, characterized the immune system in the elderly. Both processes together are suggested as the origin of most of the comorbidities of the elderly and its susceptibility to suffer cancer, chronic inflammatory diseases and new infections [6, 7]. The age-associated diseases together with the aging of the structure and function of the lungs increase the likelihood of serious progression of respiratory viral infection [8].

It has been suggested that one of the possible mechanisms underlying rapid disease progression is a cytokine storm, in which IL-6 seems to be a major mediator $[9,10]$. Previous retrospective studies indicated that an elevated level of interleukin-6 (IL-6) was associated with a high case fatality of COVID-19 infection [1]. Based on emerging information treating SARS-CoV-2-infected patients, modulating or inhibiting the IL-6 signaling pathway to mitigate the inflammatory response related to COVID-19 is an attractive idea. At present, several clinical trials are under way to evaluate the safety and efficacy of IL-6 inhibitors, with various protocols and comparators [11]. Preliminary results in a limited number of patients suggested the use of tocilizumab as promising therapeutic agent for severe and critical SARS-CoV-2 infections [12]. Nevertheless, this therapy should be used with caution taking into account the increase in serious bacterial infections reported in tocilizumab-treated patients [13].

Itolizumab is a humanized recombinant anti-CD6 monoclonal antibody (MAb) of immunoglobulin G1 (IgG1) isotype which binds to domain 1 of human CD6. This MAb was developed at the Center of Molecular Immunology (CIM, Havana, Cuba) and has demonstrated to be effective and safe in randomized clinical trials performed in psoriatic patients [14]. Itolizumab modulates T-lymphocytes activation and proliferation induced by CD6-costimulation. The regulation of downstream pathways such as pMAPK, pSTAT3 and pAKT further results in reduction of INF- $\gamma$, TNF $\alpha$ and IL- 6 both in vitro and in vivo $[15,16]$. Itolizumab is not a $\mathrm{T}$ cell depleting agent and whenever depletion occurs, it is transient in nature [17]. Recently, it was suggested the use of this MAb to treat the cytokine release syndrome detected in severe COVID-19 patients (Rodriguez PC et al., manuscript in preparation). Based on the potential use of itolizumab in this disease an expanded access trial was approved by Cuban regulatory agency (CECMED). The trial is recruiting patients with critical and severe illness; also, moderately ill patients with very high risk of developing severe symptoms.

In this paper, we show the results of the first 24 patients treated with itolizumab. The immense majority were elderly with multiple comorbidities. For the first time, it is reported that this antibody is able to decrease circulating IL-6 levels in patients with critical and severe COVID-19.

\section{Results}

\section{Characteristics of COVID-19 patients}

Twenty-four laboratory-confirmed patients, 6 males (25\%) and 18 females (75\%) were treated with itolizumab monoclonal antibody. The patients were categorized into three groups regarding the severity of illness: moderately ill (elderly with various symptoms including polypnea and $\mathrm{O} 2$ requirement), $n=11$; severely ill (SpO2 $\leq 93 \%$ while breathing room air, requiring additional $\mathrm{O} 2$ supply), $n=7$ and critically ill (patients with respiratory failure, requiring mechanical ventilation among other conditions), $n=6$. Only two patients $(8.3 \%)$ were younger than 65 years old. The average of age was 79.83 years old (Table 1).

Most of the patients presented several comorbidities at the moment of SARS-CoV-2 diagnosis predominantly hypertension, diabetes mellitus and cardiovascular diseases (Table 1).

\section{Laboratory findings}

Neutrophil number had significant differences among the three groups, especially between moderately ill and critically ill patients (4.462 vs 9.57; $p=0.013$, ANOVA, Tukey's multiple comparison test) and severely ill and critically ill patients (4.77 vs 9.57; $p=0.032$, ANOVA, Tukey's multiple comparison test). Critically and severely ill patients had higher neutrophil-to-lymphocyte ratio (NLR) than moderately ill (10.82 and 6.38 vs 3.8; $p=0.06$, Kruskall-Wallis test), although no statistical significance was achieved. The rest of the hematological 
Table 1 Demographics and baseline characteristics of moderately, severely and critically ill COVID-19 patients

\begin{tabular}{lllll}
\hline & $\begin{array}{l}\text { Moderately ill Patients } \\
(\boldsymbol{n}=\mathbf{1 1})\end{array}$ & $\begin{array}{l}\text { Severely ill patients } \\
(\boldsymbol{n}=\mathbf{7})\end{array}$ & $\begin{array}{l}\text { Critically ill patients } \\
(\boldsymbol{n}=\mathbf{6})\end{array}$ \\
\hline $\begin{array}{l}\text { Age (mean), years } \\
\text { Sex (\%) }\end{array}$ & 80 & 85.14 & 73.33 \\
$\quad \begin{array}{l}\text { Male } \\
\text { Female }\end{array}$ & $3(12.5 \%)$ & 0 & $3(12.5 \%)$ & 79.83 \\
Most frequent comorbidities (\%) & $8(33.33 \%)$ & $7(29.16 \%)$ & $3(12.5 \%)$ & $6(25 \%)$ \\
Hypertension & $8(33.33 \%)$ & & $3(12.5 \%)$ & $18(75 \%)$ \\
Diabetes mellitus & $4(16.66 \%)$ & $3(12.5 \%)$ & $3(12.5 \%)$ & $8(38.33 \%)$ \\
Cardiovascular diseases & $2(8.33 \%)$ & $1(4.16 \%)$ & $3(12.5 \%)$ & $7(29.16 \%)$ \\
COPD & $1(4.16 \%)$ & $2(8.33 \%)$ & 0 & $2(8.33 \%)$ \\
Cancer & 0 & $1(4.16 \%)$ & 0 & $1(4.16 \%)$ \\
\hline
\end{tabular}

Abbreviations: COPD Chronic obstructive pulmonary disease; NSCLC Non-small cell lung cancer

and biochemical parameters evaluated, were not different between the groups (Table 2).

\section{Serum cytokines}

There were no differences in IL-1 and TNF $\alpha$ serum concentration among the groups (data not shown). Actually, the majority of patients had no detectable levels of these inflammatory cytokines. In contrast, IL-6 was overexpressed. IL-6 levels increased with the progression of severity (Fig. 1a). The serum concentration in critically ill and severely ill patients was significantly higher than in moderately ill patients (Fig. 1b). The mean serum IL-6 was $337.4 \mathrm{pg} / \mathrm{mL}$ for critically ill patients; $95.65 \mathrm{pg} / \mathrm{mL}$, for severely ill and $26.27 \mathrm{pg} / \mathrm{mL}$ for moderately ill patients.

The baseline IL- 6 levels were related to the severity of illness when applying a receiver operator characteristic (ROC) curve $(p=0.003)$. The area under curve (AUC) of
IL-6 was 0.884 , the sensitivity $84.6 \%$, the specificity $81.8 \%$ and the cutoff value of IL-6 selected was $28.3 \mathrm{pg} /$ $\mathrm{ml}$ (Fig. 1c).

Itolizumab reduces IL- 6 in critically and severely ill patients and stabilizes its levels in moderately ill patients Serum IL-6 was measured in patients treated with itolizumab the day of the first administration and $48 \mathrm{~h}$ later $(n=15)$. The majority of patients $(86.66 \%)$ decreased or did not increase its IL- 6 values in this period. Only two patients (13.34\%) increased the serum IL-6 levels after the treatment (Fig. 2a). The mean values of IL- 6 in the critical group reduced from $290.2 \mathrm{pg} / \mathrm{mL}$ to $183.1 \mathrm{pg} /$ $\mathrm{mL}, 48 \mathrm{~h}$ after the treatment. Similarly, in severely ill patients the values dropped twice, until $61.4 \mathrm{pg} / \mathrm{ml}$. In the case of moderately ill patients, the circulating IL-6 levels were similar to the pre-treatment values (Fig. 2b).

Table 2 Laboratory parameters in moderately, severely and critically ill COVID-19 patients

\begin{tabular}{|c|c|c|c|c|c|}
\hline Baseline parameters & $\begin{array}{l}\text { Moderately ill Patients } \\
(n=11)\end{array}$ & $\begin{array}{l}\text { Severely ill patients } \\
(n=7)\end{array}$ & $\begin{array}{l}\text { Critically ill patients } \\
(n=6)\end{array}$ & All patients & $p$ value \\
\hline Hemoglobin (g/l) & $112.4 \pm 16.63$ & $104 \pm 22.35$ & $90.17 \pm 37.73$ & $102.6 \pm 27.26$ & 0.744 ANOVA \\
\hline White blood cell $\left(\times 10^{9} / \mathrm{L}\right)$ & $6.925 \pm 2.842$ & $7.92 \pm 2.366$ & $11.08 \pm 4.304$ & $8.5 \pm 3.599$ & $\begin{array}{l}0.090 \\
K-W\end{array}$ \\
\hline Neutrophil (× 109/L) & $4.462 \pm 2.055$ & $4.777 \pm 3.417$ & $9.537 \pm 4.154$ & $5.882 \pm 3.712$ & 0.012 ANOVA \\
\hline Lymphocyte $\left(\times 10^{9} / \mathrm{L}\right)$ & $1.571 \pm 0.6184$ & $1.634 \pm 0.689$ & $1.059 \pm 0.5516$ & $1.44 \pm 0.6363$ & 0.227 ANOVA \\
\hline NLR & $3.825 \pm 3.317$ & $6.389 \pm 9.717$ & $10.82 \pm 6.083$ & $6.433 \pm 6.501$ & $\begin{array}{l}0.065 \\
\text { K-W }\end{array}$ \\
\hline Platelet $\left(\times 10^{9} / \mathrm{L}\right)$ & $198.5 \pm 41.79$ & $231.2 \pm 32.69$ & $311 \pm 156.9$ & $224 \pm 88.83$ & 0.413 ANOVA \\
\hline PLR & $171.8 \pm 154.5$ & $243.2 \pm 251.9$ & $226.9 \pm 223.4$ & $227.8 \pm 195.8$ & $\begin{array}{l}0.208 \\
K-W\end{array}$ \\
\hline Triglycerides (mmol/L) & $1.023 \pm 0.2329$ & $1.197 \pm 0.2871$ & $1.962 \pm 1.081$ & $1.408 \pm 0.7893$ & 0.080 ANOVA \\
\hline $\mathrm{ALT}(\mathrm{U} / \mathrm{L})$ & $18.86 \pm 13.63$ & $18 \pm 15.75$ & $36.67 \pm 22.54$ & $24.94 \pm 18.84$ & 0.168 ANOVA \\
\hline D-Dimer (mg/l) & $0.92 \pm 0.6479$ & $2.07 \pm 1.669$ & $1.773 \pm 0.7467$ & $1.396 \pm 0.924$ & 0.744 ANOVA \\
\hline
\end{tabular}



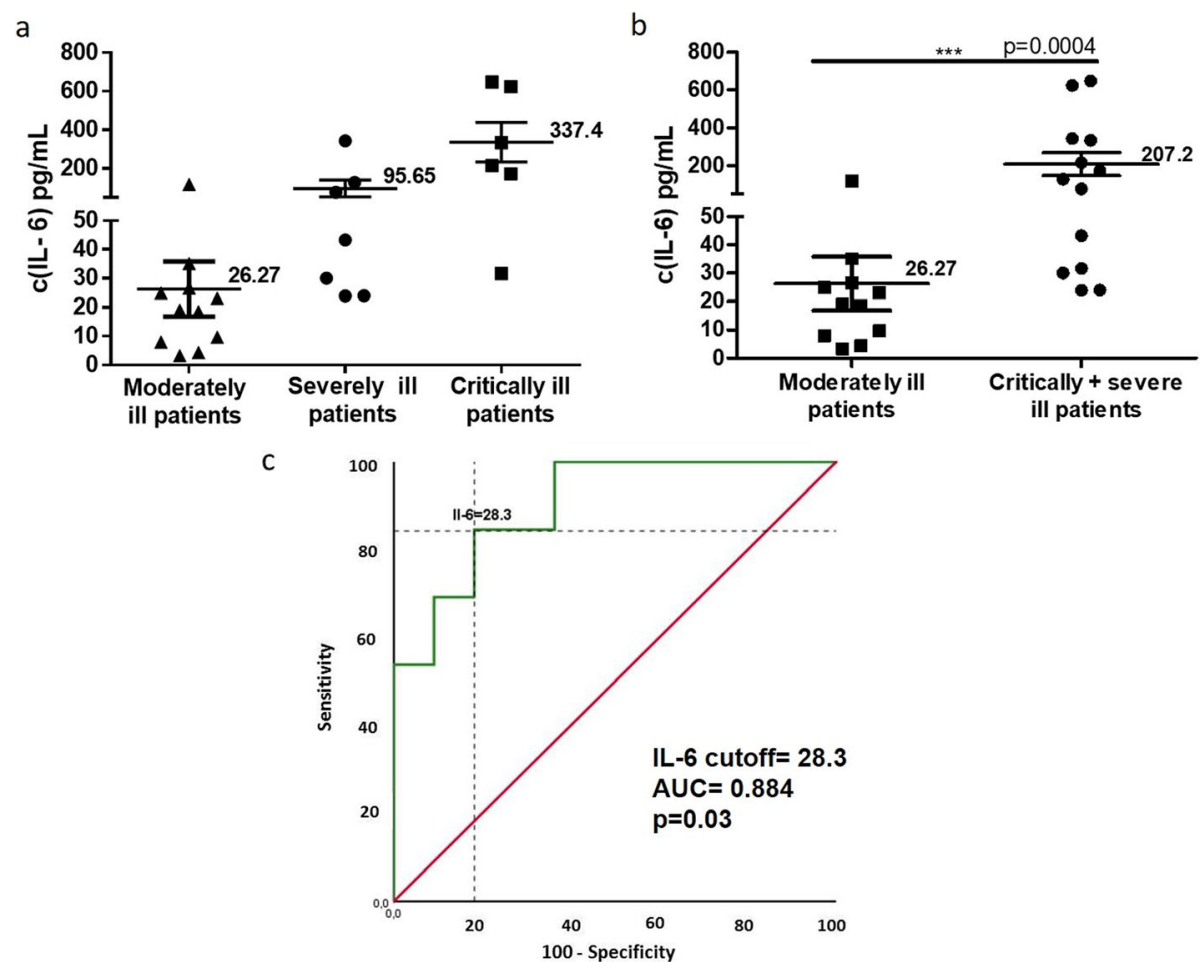

Fig. 1 IL-6 concentration in the sera of COVID-19 patients a) Mean of IL-6 levels in the three groups of COVID-19 patients. b The values are significantly higher in the group of critically and severely ill patients than in moderately ill patients. C) ROC curves of IL-6 predictive value for the severity of COVID-19. The asterisks indicate statistically significant differences among the groups $(p<0.05)(*)$ using Mann Whitney test. ROC: receiver operator characteristic; AUC: area under curve

The cutoff selected by ROC curve to stablish the association between baseline IL- 6 concentration and severity of illness was $28.3 \mathrm{pg} / \mathrm{mL}$ (Fig. 1c). Remarkably, all patients with pre-treatment circulating IL-6 levels above $28.3 \mathrm{pg} / \mathrm{mL}$, significantly decreased IL-6 concentration with one dose of itolizumab, measured $48 \mathrm{~h}$ after the administration. The magnitude of change of IL- 6 among the patients with concentrations above the cutoff has a median of reduction of $50 \mathrm{pg} / \mathrm{mL}(p=0.005$, Wilcoxon test, Fig. 2c). However, the median of change in IL-6 concentration among the patients with baseline levels below $28.3 \mathrm{pg} / \mathrm{mL}$, was $1.27 \mathrm{pg} / \mathrm{mL}$ ( $p=0.068$, Wilcoxon test).

\section{Discussion}

Since the COVID-19 outbreak, an unprecedented challenge for healthcare systems around the world has been placed [18]. According to the World Health Organization, elderly with multiple comorbidities have the highest risk of developing a severe illness [19]. The immune system of elderly is characterized by immunosenescence and inflammaging. These age-related processes are always put forward to explain the susceptibility of older adults to new infections and chronic diseases such as cardiovascular diseases, diabetes and cancer [20]. This report describes by the first time, the effect of an antiCD6 monoclonal antibody (itolizumab) decreasing circulating IL-6 in critically and severely ill elderly COVID-19 patients.

Cytokine release syndrome (CRS) was found to be the major cause of morbidity in patients infected with SARS $\mathrm{CoV}$ and MERS-CoV, previous coronavirus infections producing severe respiratory illness in humans [21]. Similar to these findings, severe COVID-19 has been described in some patients, accompanied by a similar damaging immune reaction. This severe manifestation is characterized by pronounced infiltration of macrophages and monocytes into alveoli and a pro-inflammatory response with increase of inflammatory cytokines mainly IL-6, IL-1, IFN $\gamma$ and TNF $\alpha$ [22, 23]. Different papers have demonstrated a correlation between high serum IL6 levels and adverse clinical outcomes in patients with COVID-19 [1, 24]. Similarly, an extremely high concentration of IL-6 is a driving force of cytokine storm, which may cause multiple organ dysfunctions in critically ill patients [25]. The data reported on IL-6 levels during the COVID-19 outbreak show an evident heterogeneity. A systematic review and meta-analysis of seven studies, performed by Aziz and colleagues reported the mean of serum IL-6 in $56.8 \mathrm{pg} / \mathrm{mL}(41.4-72.3 \mathrm{pg} / \mathrm{mL})$ 

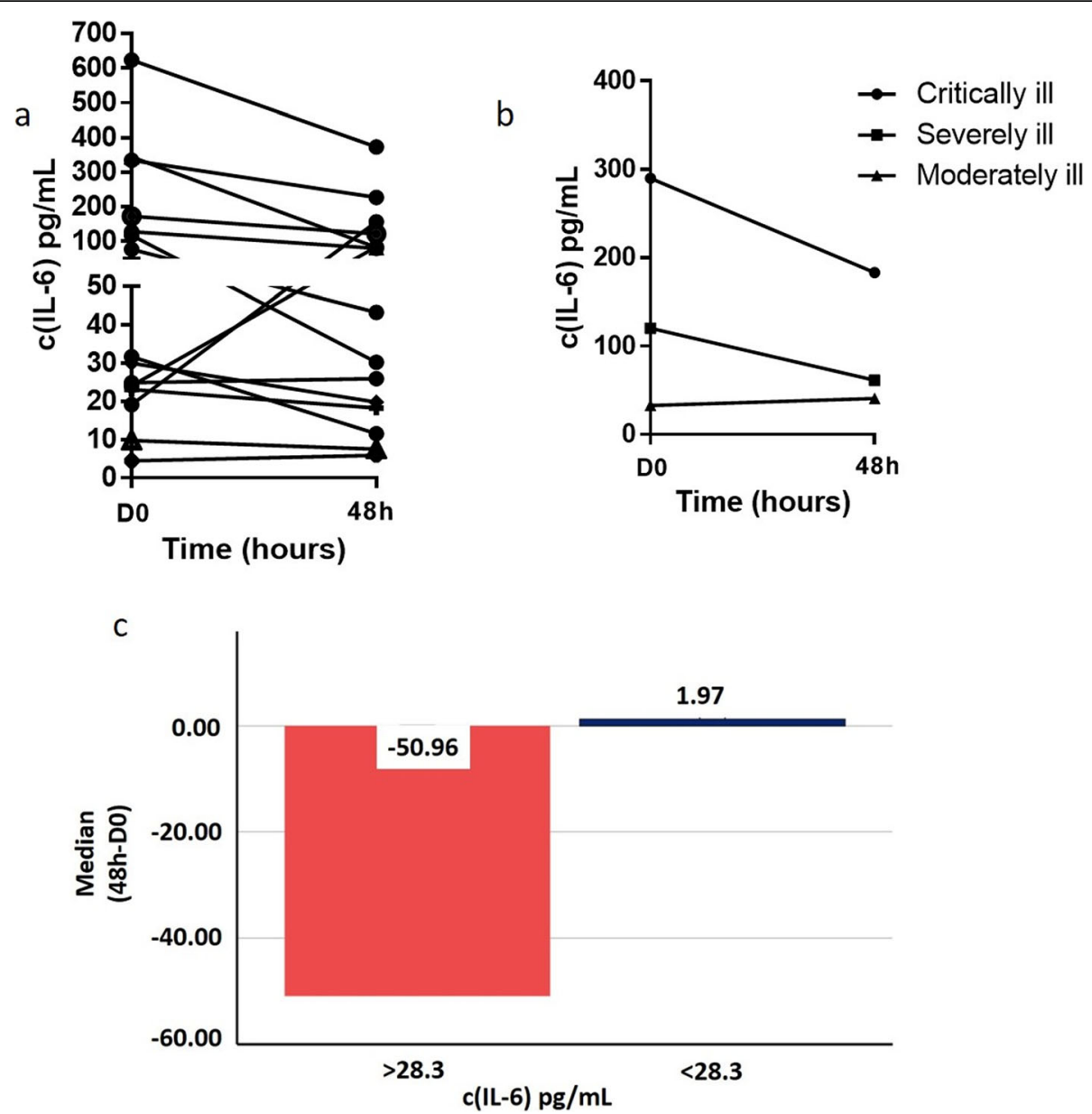

Fig. $2 \mathrm{IL}-6$ serum concentration in COVID-19 patients before and $48 \mathrm{~h}$ after the treatment with itolizumab. a Individual behavior of IL-6 values in the patients. $\mathbf{b}$ Kinetic of the mean of IL-6 levels in the three groups of patients. c Magnitude of change of IL-6 concentration $48 \mathrm{~h}$ after the administration of the first itolizumab dose in COVID 19 patients with pre-treatment levels higher than $28.3 \mathrm{pg} / \mathrm{mL}$ and lower than $28.3 \mathrm{pg} / \mathrm{mL}$. D0: Before treatment with itolizumab; $48 \mathrm{~h}: 48 \mathrm{~h}$ after the treatment

for severe COVID-19 group [26], while both our group and $\mathrm{Xu}$ et al. found higher IL-6 values for severe and critical COVID-19 patients [12]. Different methods, different specimens (serum or plasma) and the different classification of disease severity could explain this heterogeneity. However, the highest concentrations of IL- 6 are always in association with severe disease $[3,5,27,28]$, which is in line with our results.

In addition, high values of neutrophils characterized our critically and severely ill patients. Besides, as it has been previously reported $[4,23,28]$, a higher number of neutrophils and a lower number of lymphocytes, conducting to the increase of NLR, were found in the critical and severe groups compared to the moderate group of patients.

Modulation of the CRS and the severe inflammatory state in patients with COVID-19, is a very important strategy to limit the severity of COVID-19 pulmonary and systemic complications. This approach could successfully reduce the needs for intensive care support and mechanical ventilation, and eventually decrease mortality [18]. The use of immunosuppressants, specifically the IL-6 inhibitors, in the management of SARS$\mathrm{CoV}$-2-associated pneumonia is an attractive option to overcome the inflammation and CRS in the lungs. In this sense, the anti-human IL-6 receptor monoclonal antibody tocilizumab, has been used in a limited number of COVID-19 patients with promising results. Predictive biomarkers of clinical succeed using this MAb are currently investigated since some patients are not benefited [29]. In addition, the use of this antibody should be managed with caution because the high risk of bacterial infection reported among its main adverse events [13].

In our center, we have developed a first- in-class antagonistic MAb that selectively targets the CD6-ALCAM pathway, reducing the activation, proliferation and differentiation of $\mathrm{T}$ cells into pathogenic effector $\mathrm{T}$ cells and leading to a decrease of pro-inflammatory cytokine 
production (IL-6, TNF- $\alpha$ and INF $\gamma$ ). At the same time, itolizumab preserves the regulatory function of Treg cells and reduces $\mathrm{T}$ cell trafficking and infiltration at the inflammation sites [15]. The safety and efficacy of itolizumab in the treatment of patients with rheumatoid arthritis and severe chronic plaque psoriasis have been demonstrated in several clinical studies [30, 31]. According to this, itolizumab become an alternative immunomodulatory intervention that seeks to control the $\mathrm{T}$ cell hyperactivated status in order to prevent such CRS. In line with this rationale, an expanded access clinical trial is recruiting patients with critical and severe illness and moderately ill COVID-19 patients with very high risk of developing severe symptoms.

Our patients treated with itolizumab decreased the circulating IL-6 levels $48 \mathrm{~h}$ after the administration, especially in the case of critically and severely ill patients. All the patients with IL- 6 baseline levels above $28.3 \mathrm{pg} / \mathrm{mL}$, the cutoff selected by ROC curve to classify the patients with severe disease, significantly decreased the IL-6 concentration.

In the case of moderately ill patients, the baseline serum values didn't increase $48 \mathrm{~h}$ later. The immunomodulatory therapy was administered shortly after the contagion. In addition to the advance age, all moderately ill patients suffered with comorbidities, which are both risk factors associated with severity and fatal outcome in the course of COVID-19 [32, 33]. Therefore, we suggest that the stabilization of the IL- 6 levels over low values was due to the treatment with itolizumab.

Recent studies showed that IL-6 and granulocytemacrophage colony-stimulating factor (GM-CSF) could be secreted by active pathogenic $\mathrm{T}$ cells upon SARSCoV-2, also CD14 + CD16+ inflammatory monocytes activated by GM-CSF could secrete IL- 6 and other inflammatory factors $[12,34]$. Previous work demonstrated the in vitro capacity of itolizumab inhibiting the induced proliferation of peripheral blood mononuclear cells (PBMC) in the presence of ALCAM and reducing its IFN- $\gamma$, IL- 6 and TNF- $\alpha$ production [15]. Additionally, a significant decrease in the levels of IL-6, TNF- $\alpha$ and IFN- $\gamma$ was found in patients with rheumatoid arthritis and psoriasis treated with itolizumab $[16,17]$. In this study, the serum TNF- $\alpha$ concentration were undetectable in the majority of the patients, regardless of the severity of illness. Other researchers have found low levels of this cytokine in COVID-19 patients [23, 28]. Interestingly, it has been reported that levels of TNF- $\alpha$ and IL$1 \beta$, and some chemotactic cytokines (IL- 8 and MCP-1) rise early in COVID-19 hypercytokinemia, facilitating a subsequent sustained increase in IL-6 [35].

This work has some limitations regarding to the small number of patients, the short follow up of IL-6 levels in serum and the lack of the evaluation of samples from untreated patients as controls. This will be addressed in the forthcoming studies. Nevertheless, it is the first report highlighting the ability of itolizumab reducing circulating IL-6 in severe COVID-19 patients. The effect of itolizumab in the clinical outcome of treated patients remains to be analyzed.

\section{Conclusions}

The results from this work show that one dose of itolizumab reduced the baseline serum levels of IL- 6 in critically and severely ill COVID-19 patients as well as stabilized the baseline low levels in moderately ill elderly COVID-19 patients. Due to the very safe profile of itolizumab, this MAb could be an appealing option to decrease the negative outcome of the cytokine storm in COVID-19 patients.

\section{Methods}

\section{Patients and treatment}

Twenty-four patients with diagnosis of COVID-19 classified as critically ill, severely ill and moderately ill, were included in an expanded access trial to receive itolizumab, an anti -CD6 monoclonal antibody in addition to standard treatment. The diagnosis of disease severity was defined as following:

Critically ill patients were diagnosed if any of the following conditions were met: respiratory failure, requiring mechanical ventilation, septic shock, and or multiple organ failure. Severely ill patients were classified if met these conditions: $\mathrm{SpO} 2 \leq 93 \%$ while breathing room air and $\mathrm{PaO} 2 / \mathrm{FiO} 2 \leq 300 \mathrm{mmHg}$, requiring additional $\mathrm{O} 2$ supply. Moderately ill patients were elderly with various symptoms including polypnea and $\mathrm{O} 2$ requirement.

Itolizumab was administered at $200 \mathrm{mg}$ per dose intravenously. According to clinical evolution of the patient and the physician criteria, a second and even a third dose of the MAb were administered each $72 \mathrm{~h}$ after the first dose of itolizumab. Before the treatment, informed consent was obtained from enrolled patient.

The patients were treated in Manuel Piti Fajardo Universitary Hospital in Villa Clara, a central province in Cuba, after the approval of the Ethical Committee of the hospital and the Cuban Regulatory Agency (CECMED). Currently, the trial is recruiting patients.

\section{Laboratory examination}

Laboratory results included blood routine, leucocyte subsets and blood biochemical parameters were collected. The total number of lymphocytes and neutrophils in peripheral blood was counted by hemocytometer.

Serum samples for the study of circulating cytokines (IL-6, IL-1 and TNF $\alpha$ ) were obtained the day receiving the itolizumab and $48 \mathrm{~h}$ later. 
The level of inflammatory cytokines was measured using human Quantikine ELISA Kits from R\&D Systems (Minneapolis, USA): Human IL-6 Quantikine ELISA Kit (Cat\# S6050). Human IL-1 beta/IL-1F2 Quantikine ELISA Kit (Cat\# SLB50). Human TNF- alpha Quantikine ELISA Kit (Cat\# STA00D).

\section{Statistical analysis}

The baseline and demographic variables were described as percentages and the quantitative parameters as mean and standard deviation. Statistical significance between groups was evaluated using nonparametric Mann Whitney and Wilcoxon test. The receiver operator characteristic (ROC) curves were built to assess IL-6 predictive value of disease severity. The statistical analyses were performed with GraphPad 5. The statistical data were considered significant if $p<0.05$.

\begin{abstract}
Abbreviations
IL-6: Interleukin 6; MAb: Monoclonal antibody; INF-ү: Interferon gamma; TNFa: Tumour necrosis factor alpha; IgG1: Immunoglobulin G1; PMAPK: Phosphorylated mitogen-activated protein kinase; pSTAT3: Phosphorylated signal transducer and activator of transcription 3; CECMED: Centro para el control Estatal de medicamentos, equipos y dispositivos médicos; COPD: Chronic obstructive pulmonary disease; NSCL C: Non-small cell lung cancer; NLR: Neutrophil-to-lymphocyte ratio; PLR: Platelet-to-lymphocyte ratio; ALT: Alanine aminotransferase; ROC: Receiver operator characteristic; AUC: Area under curve; CRS: Cytokine release syndrome
\end{abstract}

\section{Authors' contributions}

$T C, M R, K L, D S, Z M, A C$ designed the study. NS, LMF, JB, CHe, LM, EC, CHi, AC recruited and treated the patients. GL and $M C$ contributed to acquisition of data and sample collection. DS and ALA-K performed the cytokines experiments. DS, ZM TC, MR, KL analysed and interpreted the data. DS and ZM drafted the manuscript. TC and AC critically revised the manuscript. The authors read and approved the final manuscript.

\section{Funding}

This study did not receive any financial support.

\section{Availability of data and materials}

The datasets used and analyzed during the study are available from the corresponding author on reasonable request.

\section{Ethics approval and consent to participate}

The study was approved by the Ethical Board of Manuel Piti Fajardo Universitary Hospital in Villa Clara and by the Cuban Regulatory Agency (CECMED) (RPCEC00000311).

\section{Consent for publication}

Not applicable.

\section{Competing interests}

The authors declare that they have no competing interests.

\section{Author details}

'Department of Clinical Immunology. Center of Molecular Immunology, 216 St, Corner 15, PO Box 16040, Havana, Atabey, Cuba. 'Biochemical Department. ICBP "Victoria de Girón", Calle 146 \# 3102, La Habana, Playa, Cuba. ${ }^{3}$ Manuel Piti Fajardo Universitary Hospital. Ciudad Escolar Abel Santamaría, U/M 9958, Santa Clara, Villa Clara, Cuba. ${ }^{4}$ Arnaldo Milian Castro Universitary Hospital, Arnaldo Milián Castro St, Santa Clara, Villa Clara, Cuba. ${ }^{5}$ Cardiocentro "Ernesto Che Guevara", Cuba St No 610, Santa Clara, Villa Clara, Cuba.
Received: 28 May 2020 Accepted: 6 November 2020

Published online: 14 November 2020

\section{References}

1. Chen X, Zhao B, Qu Y, Chen Y, Xiong J, Feng Y, et al. Detectable serum SARS-CoV-2 viral load (RNAaemia) is closely correlated with drastically elevated interleukin 6 (IL-6) level in critically ill COVID-19 patients. Clin Infect Dis. 2020. https://doi.org/10.1093/cid/ciaa449.

2. Wang H, Luo S, Shen Y, Li M, Zhang Z, Dong Y, et al. Multiple enzyme release, inflammation storm and hypercoagulability are prominent indicators for disease progression in COVID-19: a multi-centered, correlation study with CT imaging score. Preprint at https://ssrncom/abstract=3544837 or http:// dxdoiorg/102139/ssrn3544837 (2020). https:/doi.org/10.2139/ssrn.3544837.

3. Yang P, Ding Y, Xu Z, Pu R, Li P, Yan J, et al. Epidemiological and clinical features of COVID-19 patients with and without pneumonia in Beijing, China. Preprint at https://doiorg/101101/2020022820028068 (2020). https:// doi.org/10.1101/2020.02.28.20028068.

4. Wang D, Hu B, Hu C, Zhu F, Liu X, Zhang J, et al. Clinical characteristics of 138 hospitalized patients with 2019 novel coronavirus-infected pneumonia in Wuhan. China JAMA. 2020. https://doi.org/10.1001/jama.2020.1585.

5. Wang Z, Yang B, Li Q, Wen L, Zhang R. Clinical features of 69 cases with coronavirus disease 2019 in Wuhan, China. Clin Infect Dis. 2020. https://doi. org/10.1093/cid/ciaa272.

6. Fulop T, Witkowski JM, Olivieri F, Larbi A. The integration of inflammaging in age-related diseases. Semin Immunol. 2018;40:17-35. https://doi.org/10. 1016/.smim.2018.09.003

7. Kirkwood KL. Inflammaging. Immunol Investig. 2018;478:770-3. https://doi. org/10.1080/08820139.2018.1552392.

8. Har-Noy M, Or R. Allo-priming as a universal anti-viral vaccine: protecting elderly from current COVID-19 and any future unknown viral outbreak. J Transl Med. 2020;181:196. https://doi.org/10.1186/s12967-020-02363-3.

9. Mehta P, McAuley DF, Brown M, Sanchez E, Tattersall RS, Manson JJ, et al. COVID-19: consider cytokine storm syndromes and immunosuppression. Lancet. 2020;39510229:1033-4. https://doi.org/10.1016/S01406736(20)30628-0.

10. Hirano T, Murakami M. COVID-19: a new virus, but a familiar receptor and cytokine release syndrome. Immunity. 2020. https://doi.org/10.1016/j. immuni.2020.04.003.

11. Jamilloux Y, Henry T, Belot A, Viel S, Fauter M, El Jammal T, et al. Should we stimulate or suppress immune responses in COVID-19? Cytokine and anticytokine interventions. Autoimmun rev:102567. 2020. https://doi.org/10. 1016/j.autrev.2020.102567.

12. Xu X, Han M, Li T, Sun W, Wang D, Fu B, et al. Effective treatment of severe COVID-19 patients with tocilizumab. Proc Natl Acad Sci U S A. 2020;11720: 10970-5. https://doi.org/10.1073/pnas.2005615117.

13. Choy EH, De Benedetti F, Takeuchi T, Hashizume M, John MR, Kishimoto T. Translating IL-6 biology into effective treatments. Nat Rev Rheumatol. 2020. https://doi.org/10.1038/s41584-020-0419-z.

14. Dogra S, Uprety S, Suresh SH. Itolizumab, a novel anti-CD6 monoclonal antibody: a safe and efficacious biologic agent for management of psoriasis. Expert Opin Biol Ther. 2017;173:395-402. https://doi.org/10.1080/14712598. 2017.1279601.

15. Nair P, Melarkode R, Rajkumar D, Montero E. CD6 synergistic co-stimulation promoting proinflammatory response is modulated without interfering with the activated leucocyte cell adhesion molecule interaction. Clin Exp Immunol. 2010;1621:116-30. https://doi.org/10.1111/j.1365-2249.2010.04235.x.

16. Aira LE, Lopez-Requena A, Fuentes D, Sanchez L, Perez T, Urquiza A, et al. Immunological and histological evaluation of clinical samples from psoriasis patients treated with anti-CD6 itolizumab. MAbs. 2014;63:783-93. https:// doi.org/10.4161/mabs.28376.

17. Aira LE, Hernandez P, Prada D, Chico A, Gomez JA, Gonzalez Z, et al, Immunological evaluation of rheumatoid arthritis patients treated with itolizumab. MAbs. 2016;81:187-95. https://doi.org/10.1080/19420862.2015. 1105416.

18. Arnaldez Fl, O'Day SJ, Drake CG, Fox BA, Fu B, Urba WJ, et al. The Society for Immunotherapy of Cancer perspective on regulation of interleukin-6 signaling in COVID-19-related systemic inflammatory response. J Immunother Cancer. 2020;8(1). https://doi.org/10.1136/jitc-2020-000930.

19. McMichael TM, Currie DW, Clark S, Pogosjans S, Kay M, Schwartz NG, et al. Epidemiology of Covid-19 in a long-term Care Facility in King County, Washington. N Engl J Med. 2020. https://doi.org/10.1056/NEJMoa2005412. 
20. Pawelec G, Weng NP. Can an effective SARS-CoV-2 vaccine be developed for the older population? Immun Ageing. 2020;17:8. https://doi.org/10.1186/ s12979-020-00180-2.

21. Channappanavar R, Perlman S. Pathogenic human coronavirus infections: causes and consequences of cytokine storm and immunopathology. Semin Immunopathol. 2017;395:529-39. https://doi.org/10.1007/s00281-017-0629-x.

22. Conti P, Ronconi G, Caraffa A, Gallenga CE, Ross R, Frydas I, et al. Induction of pro-inflammatory cytokines (IL-1 and IL-6) and lung inflammation by Coronavirus-19 (COVI-19 or SARS-CoV-2): anti-inflammatory strategies. J Biol Regul Homeost Agents. 2020;34(2). https://doi.org/10.23812/CONTI-E.

23. Qin C, Zhou L, Hu Z, Zhang S, Yang S, Tao Y, et al. Dysregulation of immune response in patients with COVID-19 in Wuhan, China. Clin Infect Dis. 2020. https://doi.org/10.1093/cid/ciaa248.

24. Moore JB, June CH. Cytokine release syndrome in severe COVID-19. Science. 2020;3686490:473-4. https://doi.org/10.1126/science.abb8925.

25. Zumla A, Hui DS, Azhar El, Memish ZA, Maeurer M. Reducing mortality from 2019-nCoV: host-directed therapies should be an option. Lancet. 2020; 39510224:e35-e6. https://doi.org/10.1016/S0140-6736(20)30305-6.

26. Aziz M, Fatima R, Assaly R. Elevated interleukin-6 and severe COVID-19: a meta-analysis. J Med Virol. 2020. https://doi.org/10.1002/jmv.25948.

27. Yang $X, Y u$ Y, Xu J, Shu H, Xia J, Liu H, et al. Clinical course and outcomes of critically ill patients with SARS-CoV-2 pneumonia in Wuhan, China: a singlecentered, retrospective, observational study. Lancet Respir Med. 2020;85: 475-81. https://doi.org/10.1016/S2213-2600(20)30079-5.

28. Zhang J, Yu M, Tong S, Liu LY, Tang LV. Predictive factors for disease progression in hospitalized patients with coronavirus disease 2019 in Wuhan, China. J Clin Virol. 2020;127:104392. https://doi.org/10.1016/j.jcv. 2020.104392.

29. Marfella R, Paolisso P, Sardu C, Bergamaschi L, D'Angelo EC, Barbieri M, et al. Negative impact of hyperglycaemia on tocilizumab therapy in Covid-19 patients. Diabetes Metab. 2020. https://doi.org/10.1016/j.diabet.2020.05.005

30. Krupashankar DS, Dogra S, Kura M, Saraswat A, Budamakuntla L, Sumathy

TK, et al. Efficacy and safety of itolizumab, a novel anti-CD6 monoclonal antibody, in patients with moderate to severe chronic plaque psoriasis: results of a double-blind, randomized, placebo-controlled, phase-III study. J Am Acad Dermatol. 2014;713:484-92. https://doi.org/10.1016/j.jaad.2014.01. 897.

31. Rodriguez PC, Prada DM, Moreno E, Aira LE, Molinero C, Lopez AM, et al. The anti-CD6 antibody itolizumab provides clinical benefit without lymphopenia in rheumatoid arthritis patients: results from a 6-month, openlabel phase I clinical trial. Clin Exp Immunol. 2018;1912:229-39. https://doi. org/10.1111/cei.13061.

32. Shahid Z, Kalayanamitra R, McClafferty B, Kepko D, Ramgobin D, Patel R, et al. COVID-19 and older adults: what we know. J Am Geriatr Soc. 2020;685: 926-9. https://doi.org/10.1111/jgs.16472.

33. Liu K, Chen Y, Lin R, Han K. Clinical features of COVID-19 in elderly patients: a comparison with young and middle-aged patients. J Inf Secur. 2020;806: e14-e8. https://doi.org/10.1016/j.jinf.2020.03.005

34. Zhou YFB, Zheng X, Wang D, Zhao C, Qi Y, Sun R, Tian Z, Xu X, Wei H. Aberrant pathogenic GM-CSF+ T cells and inflammatory CD14+CD16+ monocytes in severe pulmonary syndrome patients of a new coronavirus. Preprint at https://wwwbiorxivorg/content/101101/20200212945576v1. 2020, 2020. https://doi.org/10.1101/2020.02.12.945576.

35. Babaha F, Rezaei N. Primary immunodeficiency diseases in COVID-19 pandemic: a predisposing or protective factor? Am J Med Sci. 2020. https:// doi.org/10.1016/j.amjms.2020.07.027.

\section{Publisher's Note}

Springer Nature remains neutral with regard to jurisdictional claims in published maps and institutional affiliations.

Ready to submit your research? Choose BMC and benefit from:

- fast, convenient online submission

- thorough peer review by experienced researchers in your field

- rapid publication on acceptance

- support for research data, including large and complex data types

- gold Open Access which fosters wider collaboration and increased citations

- maximum visibility for your research: over $100 \mathrm{M}$ website views per year

At BMC, research is always in progress.

Learn more biomedcentral.com/submissions 